\title{
The Use of a Locking Plate for the Treatment of Femoral Diaphyseal Fracture in Giant Anteaters (Myrmecophaga tridactyla)
}

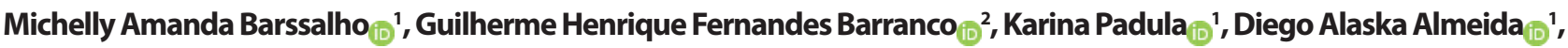 \\ Gracila Heitor de Oliveira ${ }^{1}{ }^{1}$, Maria Stella Fernandes Vilella ${ }_{\mathbb{D}}{ }^{1}$, Stephanie Fernandez ${ }_{(\mathbb{D})}{ }^{1}$, \\ Tatiana Morosini de Andrade Cruvinel $\mathbb{C}_{(\mathbb{0}}^{1} \&$ Victor José Vieira Rossetto ${ }_{(0)}^{3}$
}

\begin{abstract}
Background: The giant anteater is considered a species vulnerable to trauma due to being slow and, therefore, vulnerable to long bone fractures, such as femoral fracture. Locking plates have the potential to restore and maintain fractured bone stability, as well as reduce damage to the vascular supply. This study aims at reporting cases of two giant anteaters subjected to femoral osteosynthesis using locking plates.

Cases: Two giant anteaters presenting non-weight bearing lameness on the right pelvic limbs were evaluated, diagnosed with femoral fracture of unknown etiology and submitted to osteosynthesis. A clinical evaluation was performed under chemical restraint for the adult animal and physical restraint for the young one. Crepitation and swelling in the right femur topography led to a radiographic examination, which showed a complete and transverse diaphyseal fracture of the right femur in both cases. The first one was an adult male and was subjected to osteosynthesis of the right femur using a locking plate. Once anesthetized, the animal was placed in left lateral recumbency, and the right pelvic limb was clipped and sterilized. A craniolateral incision was made to expose the femoral diaphysis. A large amount of fibrous-looking tissue was found and removed. Subsequently, the fracture was reduced and the locking plate system was positioned on the craniolateral side of the femur. An osteotomy of the femoral trochanteric crest was required to position the implant. The overlying fascia lata was closed using monofilament suture in a simple continuous pattern. The closure of the subcutaneous tissue and skin was performed using a Cushing pattern and simple interrupted pattern, respectively. Immediate postoperative radiographic examinations showed fracture reduction and bone axis alignment, with a properly positioned implant. The surgical wound was cleaned daily with $0.5 \%$ aqueous chlorhexidine solution. Seven days after surgery, the animal had a partial dehiscence at the suture site, with bone and plate exposure. Wound healing by second intention was initiated. At 127 days after surgery, a radiographic examination showed periosteal bone proliferation in the middle third of the right femur and that the bone implants were well-positioned. The second case was of a young $3.68 \mathrm{~kg}$ female anteater. The surgery was performed as described for the adult one, but there was no fibrosis at the fracture site and the osteotomy of the femoral trochanteric crest was not required. Closure of the fascia lata, subcutaneous tissue, and skin was performed as in Case 1. An immediate postoperative radiographic examination showed fracture reduction, bone axis alignment, and a properly positioned implant. The surgical wound was cleaned daily with $0.5 \%$ aqueous chlorhexidine solution. On the day of the surgery, the animal could already bear weight on its right pelvic limb, presenting discrete lameness with gradual improvement. Twenty-three days after surgery, a radiographic examination showed moderate periosteal bone proliferation in the middle third of the right femur. The bone implant was still well-positioned and bone healing was achieved around the 40th post-operative day.

Discussion: The cases are very similar, but the younger anteater's femoral trochanteric crest didn't prevent positioning the plate. The fibrosis observed on the adult specimen is indicative of a chronic fracture, which may explain, in conjunction with the post-surgical complications, the longer time required for bone healing in the adult animal. Even so, both animals recovered fully and it's safe to deduce that the locking plate is an adequate option for internal fixation in transverse diaphyseal femoral fractures in both adult and young giant anteaters.
\end{abstract}

Keywords: fracture fixation, internal; animals, wild, mammals.

DOI: $10.22456 / 1679-9216.111080$

Received: 18 February 2021

Accepted: 10 June 2021

Published: 17 August 2021

${ }^{1}$ Centro Universitário de Rio Preto (UNIRP), São José do Rio Preto, SP, Brazil. ${ }^{2}$ Faculdade de Ciências Agrárias e Veterinárias (FCAV), Universidade Estadual Paulista (UNESP) - Campus de Jaboticabal, Jaboticabal, SP. ${ }^{3}$ Faculdade de Ensino Superior e Formação Integral (FAEF), Garça, SP. CORRESPONDENCE: M. A. Barssalho [barssalho@ hotmail.com]. Rua Elisiário Soares de Albergaria Junior n. 307. CEP 15400-000 Olímpia, SP, Brazil. 


\section{INTRODUCTION}

The giant anteater (Myrmecophaga tridactyla Linnaeus, 1758) is considered a vulnerable species by the International Union for Conservation of Nature (IUCN) due to the loss of its habitat as a consequence of human actions. In addition, because it is considered a slow animal, the giant anteater is often subjected to fractures resulting from automobile accidents $[8,9]$.

Femoral fractures account for $45 \%$ of all fractures involving long bones and require an internal fixation provided by plate and screws for rapid bone healing and functional restoration of the injured limb [4]. Among the various bone plate systems, the locking plate is of particular interest because it provides limited bone-to-implant contact, reduces damage to the vascular supply, and reduces the risk of orthopedic complications [7]. Although femoral fractures and osteosynthesis in giant anteaters are common for Brazilian wildlife veterinarians, there are few scientific reports describing the surgical technique and no reports of locking plates being used as the sole fixation method.

Due to the concern for the giant anteater's preservation and conservation, this study aims to report 2 cases of femoral fractures in anteaters subjected to femoral osteosynthesis using a locking plate.

\section{CASES}

Case 1. An adult $41.5 \mathrm{~kg}$ male anteater with a history of non-weight bearing lameness on the right pelvic limb with unknown etiology, was evaluated. The clinical evaluation of the animal was performed under chemical restraint with ketamine hydrochloride ${ }^{1}$ [Dopalen $\left.^{\circledR}-10 \mathrm{mg} / \mathrm{kg}, \mathrm{IM}\right]$ and midazolam maleate ${ }^{2}$ [Dormire ${ }^{\circledR}-0.3 \mathrm{mg} / \mathrm{kg}, \mathrm{IM}$ ], revealing crepitation and swelling in the location of the right femur. A radiographic examination was then performed with mediolateral and craniocaudal projections, revealing the presence of a complete, transverse diaphyseal fracture of the right femur (Figure 1). The full blood count and blood chemistry assay presented values within the normal range for the species [8].

Therefore, the animal was subjected to osteosynthesis of the right femur using a locking plate. Preanesthetic medication with ketamine hydrochloride 1 $[10 \mathrm{mg} / \mathrm{kg}]$ and midazolam maleate ${ }^{2}[0.3 \mathrm{mg} / \mathrm{kg}]$ was administered intramuscularly. Propofol ${ }^{2}$ [Propovan ${ }^{\circledR}$ dose response, starting with $1 \mathrm{mg} / \mathrm{kg}$ ] was administered intravenously for anesthetic induction. Subsequently, an epidural block with morphine sulfate pentahydrate2 [Dimorf ${ }^{\circledR}-0.1 \mathrm{mg} / \mathrm{kg}$ ] and isobaric bupivacaine hydrochloride2 [Neocaína ${ }^{\circledR}-0.2 \mathrm{mg} / \mathrm{kg}$ ] was performed. Anesthesia was maintained with isoflurane2 [Isoforine $\left.^{\circledR}\right]$ diluted in $100 \%$ oxygen and vaporized in an open system. The animal was placed in left lateral recumbency, and the right pelvic limb was clipped and sterilized with $2 \%$ chlorhexidine detergent 3 [Riohex ${ }^{\circledR}$ ] and $0.5 \%$ alcoholic chlorhexidine 3 [Riohex $\left.{ }^{\circledR}\right]$ solution. A craniolateral incision was made to expose the femoral diaphysis [16,17]. A large amount of fibrouslooking tissue was found and removed with a rugine. Subsequently, the fracture was reduced and the locking plate system $4,4.5 \mathrm{~mm}$ in length with 12 holes, was positioned on the craniolateral side of the femur. An osteotomy of the femoral trochanteric crest with an oscillating saw was required to position the implant (Figure 2). Eight locking screws were positioned, 4 in the segment proximal to the fracture and 4 in the segment distal to the fracture. The overlying fascia lata was closed using monofilament suture5 (Nylon) in a simple continuous pattern. The closure of the subcutaneous tissue and skin was performed with 2-0 monofilament suture5 (Nylon), using a Cushing pattern and a simple interrupted pattern, respectively. Immediate postoperative mediolateral and craniocaudal radiographic examinations showed fracture reduction and bone axis alignment, with a properly positioned implant. Sodium cephalothin6 [Cephalothin sodium $30 \mathrm{mg} / \mathrm{kg}$, BID, IM, for 21 days], tramadol hydrochloride7 [Tramadol hydrochloride - $4 \mathrm{mg} / \mathrm{kg}, \mathrm{BID}, \mathrm{SC}$, for 21 days], sodium dipyrone8 [Febrax ${ }^{\circledR}-25 \mathrm{mg} / \mathrm{kg}$, $\mathrm{BID}, \mathrm{SC}$, for 17 days), and ranitidine hydrochloride7 [Ranitidine hydrochloride - $1 \mathrm{mg} / \mathrm{kg}, \mathrm{BID}, \mathrm{SC}$, for 21 days] were prescribed for the postoperative period. The surgical wound was cleaned daily with $0.5 \%$ aqueous chlorhexidine solution ${ }^{3}$.

Seven days after surgery, the animal had a partial suture dehiscence with bone and plate exposure, probably because the animal spent most of the time in right lateral recumbency. Wound healing by second intention was initiated by applying a non-adherent dressing every three days, as well as applying Ringer's lactate solution and castor oil ointment ${ }^{9}$ [Ricinus Assept $\left.t^{\circledR}\right]$ topically. A padded bandage was also applied to the right pelvic limb. After 127 days, a radiographic examination showed periosteal bone proliferation in the middle third of the right femur (Figure 3). The 
bone implants were well-positioned, and no radiolucent areas, suggestive of bone lysis, were observed. The patient presented full remission and was released back into the wild.

Case 2. A young $3.68 \mathrm{~kg}$ female anteater with a history of non-weight bearing lameness on the right pelvic limb with unknown etiology, was evaluated. A clinical evaluation of the animal under physical restraint revealed crepitation and swelling at the location of the right femur. A radiographic examination with mediolateral and craniocaudal projections revealed the presence of a complete, transverse diaphyseal fracture of the right femur (Figure 4). The full blood count and blood chemistry assay presented values within the normal range for the species [8].

Therefore, the animal was subjected to osteosynthesis of the right femur using a locking plate. Preanesthetic medication with morphine pentahydrate ${ }^{2}$ [Dimorf ${ }^{\circledR}-0.1 \mathrm{mg} / \mathrm{kg}, \mathrm{IM}$ ] was administered, followed by anesthetic induction with propofol2 [Propovan ${ }^{\circledR}$ dose response, starting at $1 \mathrm{mg} / \mathrm{kg}$, IV]. An epidural block with morphine sulfate pentahydrate2 [Dimorf ${ }^{\circledR}$ - $0.1 \mathrm{mg} / \mathrm{kg}$ ] and isobaric bupivacaine hydrochloride ${ }^{2}$ [Neocaína ${ }^{\circledR}-0.2 \mathrm{mg} / \mathrm{kg}$ ] was performed. Anesthesia was maintained with isoflurane ${ }^{2}$, diluted in $100 \%$ oxygen and vaporized in an open system. The animal was placed in left lateral recumbency, and the right pelvic limb was clipped and sterilized with $2 \%$ chlorhexidine detergent ${ }^{3}$ and $0.5 \%$ chlorhexidine alcohol ${ }^{3}$ solutions. A craniolateral incision was made to expose the femoral diaphysis. Subsequently, the fracture was reduced and the locking plate system ${ }^{4}, 2.0 \mathrm{~mm}$ in length with 8 holes, was positioned on the craniolateral surface of the femur. The osteotomy of the femoral trochanteric crest was not required in this case. Two screws were positioned in the segment proximal to the fracture and three in the distal segment. Closure of the fascia lata, subcutaneous tissue, and skin was performed as in Case 1, using a 3-0 monofilament suture (Nylon) $)^{5}$. An immediate postoperative radiographic examination with mediolateral and craniocaudal projections, revealed fracture reduction, bone axis alignment, and a properly positioned implant (Figure 5). Sodium cephalothin6 [Cephalothin sodium - $30 \mathrm{mg} / \mathrm{kg}$, BID, IM, for 12 days] and tramadol hydrochloride7 [Tramadol hydrochloride - $2 \mathrm{mg} / \mathrm{kg}$, BID, SC, for 14 days] were prescribed for the postoperative period. The surgical wound was cleaned daily with $0.5 \%$ aqueous chlorhexidine solu- $\operatorname{tion}^{3}\left[\right.$ Riohex $\left.^{\circledR}\right]$. On the same day of surgery, the animal could already bear weight on its right pelvic limb, presenting discrete lameness with gradual improvement later. Twenty-three days after surgery, a radiographic examination revealed moderate periosteal bone proliferation in the middle third of the right femur. The bone implant was still well-positioned. Bone healing was achieved around the 40th post-operative day. The animal was fully rehabilitated, but due to its young age was kept in captivity.

\section{DISCUSSION}

Femoral fractures account for approximately $20 \%$ to $45 \%$ of all long bone fractures, probably due to the greater exposure of the bone to different traumatic agents $[4,13]$. In fact, both animals in this study had femoral fractures. Femoral fractures, especially when considering the species reported, must be treated with surgical intervention and internal fixation due to the large muscle mass around the femur [4]. Among the fixation methods, the locking plate, a system characterized by having threaded holes that allow the fitting of the screws to the plate, is of particular interest [6].

Locking plates have biomechanical advantages over conventional orthopedic implants, such as neutralization plates, dynamic compression plates, and reduced contact dynamic compression plates, since they promote greater resistance and angular stability to fractures, especially in large animals such as the giant anteater [4]. Several clinical changes are observed in wild animals due to stress, which may interfere with bone healing when they are subjected to containment and frequent manipulation [11].

The insertion of the bone plate was technically difficult during the surgical procedure in case 1 , since the trochanteric crest is prominent in adult anteaters [10]. Therefore, trochanteric osteotomy should be considered when performing the procedure in adult animals. There are 2 others reports of femoral osteosynthesis in giant anteaters: the first one used an intramedullary pin and was unsuccessful due to mobility and osteomyelitis, leading to the euthanasia of the animal [2]. The second one, taking in account the first report, used a locking plate and an intramedullary pin [1]. Since the trochanteric osteotomy was not performed, the locking plate was placed in a more cranial position in order to avoid the crest, which is not the ideal placement. To account for this change, 


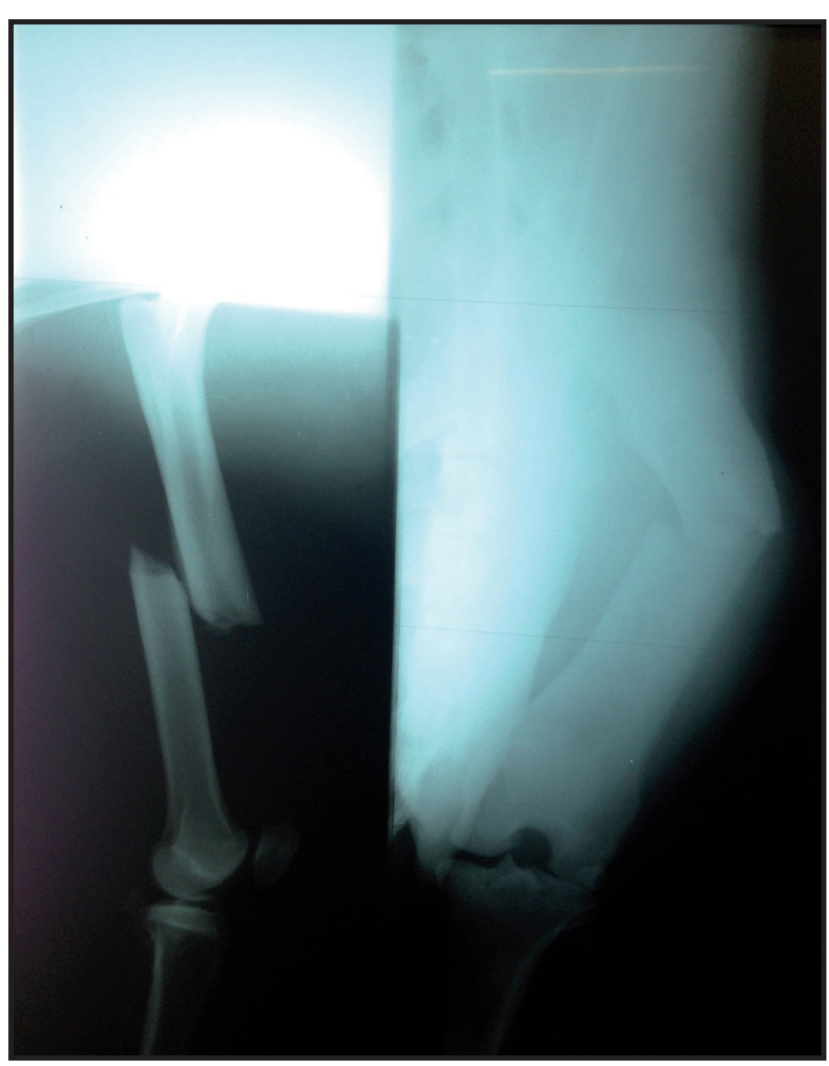

Figure 1. Mediolateral and craniocaudal projections of the right femur show a complete transversal diaphyseal fracture. Giant anteater (Case 1).

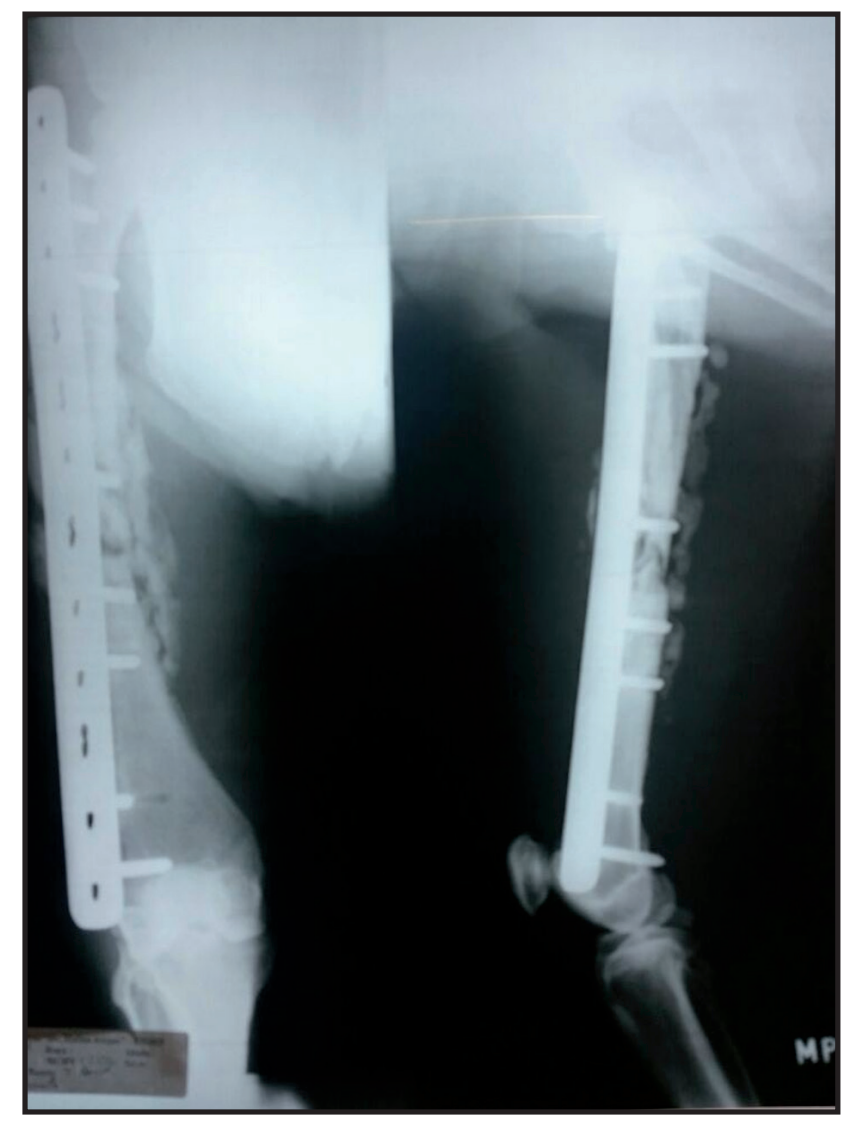

Figure 3. Right femur radiographic image 127 days after surgery shows periosteal bone proliferation in the middle third of the right femur. Giant anteater (Case 1).

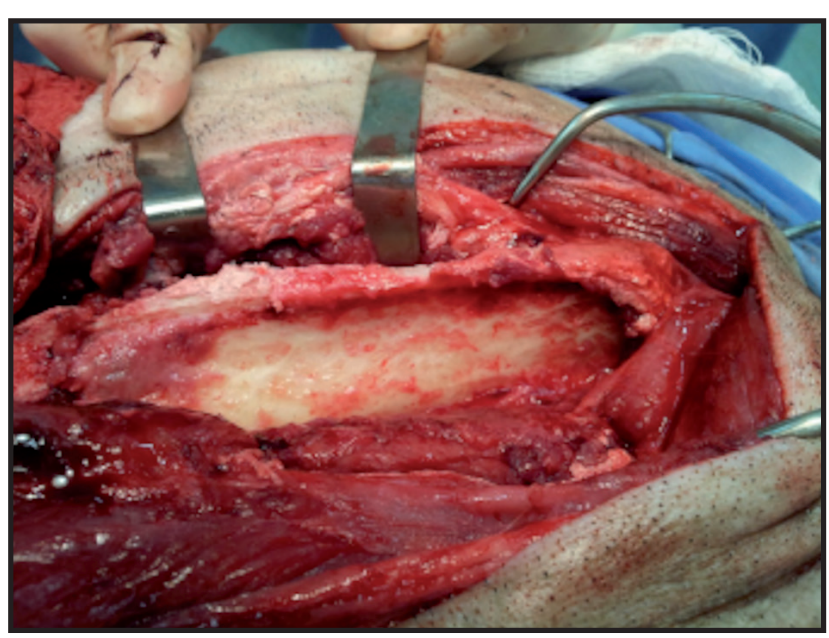

Figure 2. Adults presents an exuberant trochanteric crest at the location so the osteotomy of the crest must be performed to allow a better fixation of the locking plate. Giant anteater (Case 1).

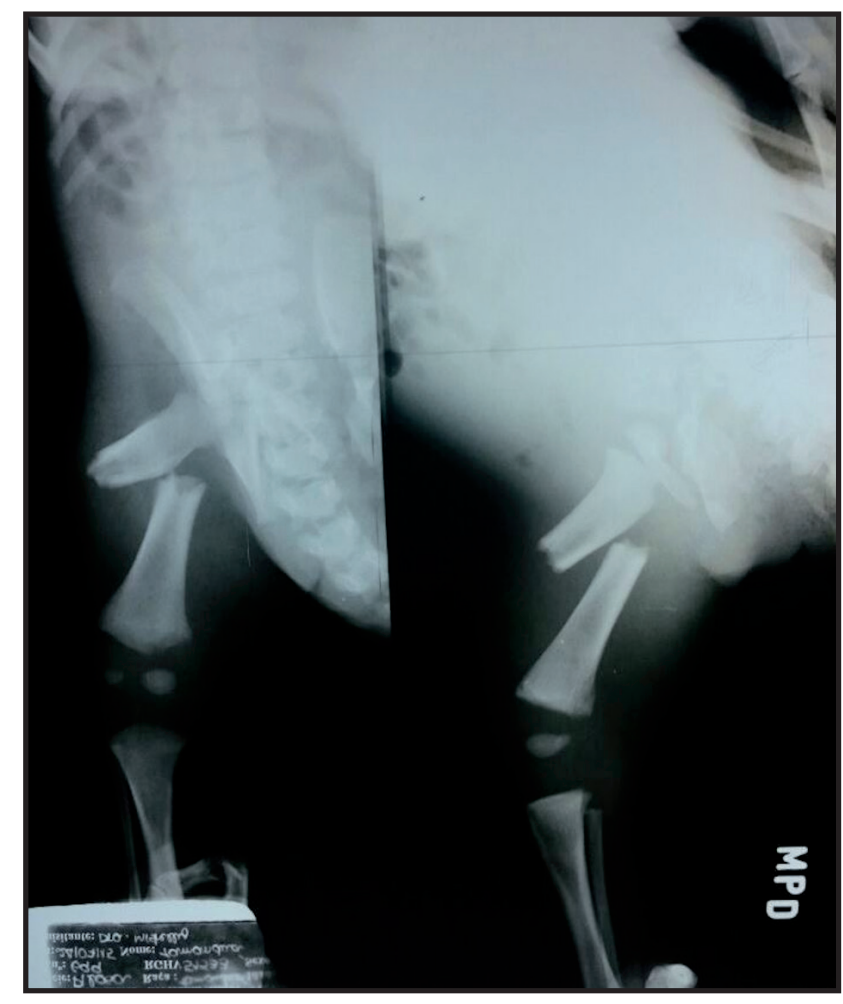

Figure 4. Mediolateral and craniocaudal projections of the right femur show a complete transverse diaphyseal fracture. Giant anteater (Case 2).

they chose to insert an intramedullary pin as well so the implants would provide a good stability [1].

Despite the complications in Case 1, both animals presented early weight-bearing and bone union, even though more time was needed in Case 1. However, there is not enough data in the literature to properly compare the healing time of anteaters and, therefore, it is not possible to state with certainty that Case 1 presented a delayed union. 


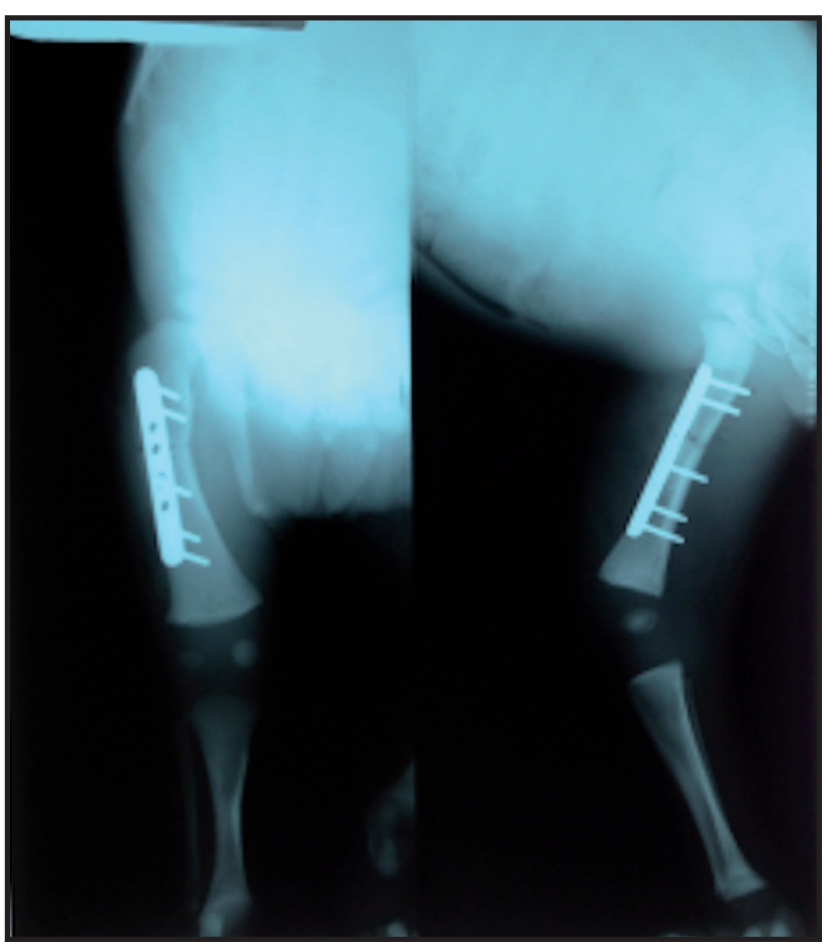

Figure 5. Right femur radiographic image 23 days after surgery shows mild periosteal bone proliferation in the middle third of the right femur. Giant anteater (Case 2).

The possible delayed bone healing in Case 1 may be related to the chronicity of the fracture, characterized by the presence of a large amount of fibrotic tissue around the bone fragments at the time of the surgical procedure. This tissue was removed to allow fracture reduction, which may have resulted in increased periosteal injury and, consequently, lower blood supply to the bone $[4,12]$. Another factor that may interfere with bone healing is the stability at the fracture site. Excessive movements of distraction and approximation at the fracture site hinder the proliferation and migration of osteogenic cells and result in delayed bone healing [5]. In fact, instability at the fracture site and the resulting failure of the implant with absence of bone healing was observed in an adult anteater with an oblique diaphyseal femoral fracture that was subjected to osteosynthesis using an intramedullary pin [2].

However, we believe that the presence of instability at the fracture site is not the reason for the probable delayed bone healing in Case 1, due to the low periosteal/endosteal proliferation around the bone segments observed in the postoperative radiographic examination [3].

Therefore, we conclude that a locking plate may be an adequate option for internal fixation of transverse diaphyseal femoral fractures, both in adult and young giant anteaters. However, we emphasize the importance of prior knowledge of anatomical aspects, such as the presence of the trochanteric crest in the femur in adult giant anteaters. Moreover, further studies are necessary to evaluate bone healing in these animals.

\section{MANUFACTURERS}

${ }^{1}$ Ceva Saúde Animal Ltda. Paulínia, SP, Brazil.

${ }^{2}$ Cristália Produtos Químicos Farmacêuticos Ltda. Itapira, SP, Brazil.

${ }^{3}$ Rioquímica Ltda. São José do Rio Preto, SP, Brazil.

${ }^{4}$ Cãomédica Ltda. Campinas, SP, Brazil.

${ }^{5}$ Shalon fios cirúrgicos Ltda. São Luís de Montes Belos, GO, Brazil.

${ }^{6}$ Antibióticos do Brasil Ltda. Cosmópolis, SP, Brazil.

${ }^{7}$ Teuto Brasileiro S.A. Anápolis, GO, Brazil.

${ }^{8}$ Lema Biologic do Brasil Ltda. Lagoa Santa, MG, Brazil.

${ }^{9}$ Vansil Indústrias Comércio e Representações Ltda. Descalvado, SP, Brazil.

Acknowledgements. We gratefully thank the Hospital "Dr. Halim Atique Neto" of the Rio Preto University Center (UNIRP) and the Wildlife Care Department (SACCAS) of UNIRP for the assistance in conducting the reported cases.

Declaration of interest. The authors report no conflicts of interest. The authors alone are responsible for the content and writing of the paper.

\section{REFERENCES}

1 Alves E.G.L., Oliveira G.C.A., Magalhães T.V., Teodoro A.N., Eulálio F.H.F., Rosado I.R., Sampaio R.L. \& Yudi C.K. 2020. Osteossíntese femoral associada ao biovidro $60 \mathrm{~S}$ em tamanduá-bandeira: relato de caso. Arquivo Brasileiro de Medicina Veterinária e Zootecnia. 72(3): 737-743.

2 Bonnon M., Souza L.O. \& Ortunho V.V. 2015. Fixação com pino intramedular em fratura do fêmur em Tamanduá Bandeira, Myrmecophaga Tridactyla - Linnaeus, 1758: Relato de caso. Revista Brasileira de Higiene e Sanidade Animal. 9(3): 535-542.

3 Denny H.R. \& Butterworth S.J. 2006. Cicatrização Óssea. In: Cirurgia Ortopédica em Cães e Gatos. 4.ed. São Paulo: Roca, pp.8-9.

4 Guiot L.P., Demianiuk R.M. \& Déjardin L.M. 2012. Fractures of the Femur. In: Tobias K.M. \& Johnston S.A. (Eds). Veterinary Surgery: Small Animal. St. Louis: Elsevier Saunders, pp.865-905. 
5 Marsell R. \& Einhorn T.A. 2011. The biology of fracture healing. Injury. 42(6): 551-555.

6 Miller D.L. \& Goswami T. 2007. A review of locking compression plate biomechanics and their advantages as internal fixators in fracture healing. Clinical Biomechanics. 22(10): 1049-1062.

7 Milton J.L. 1998. Fraturas de fêmur. In: Slatter D. (Ed). Manual de Cirurgia de Pequenos Animais. 2.ed. São Paulo: Manole, pp.2135-2148.

8 Miranda F. 2014. Cingulata (Tatus) e Pilosa (Preguiças e Tamanduás). In: Cubas Z.S., Silva J.C.R. \& Catão-Dias J.L. (Eds). Tratado de Animais Selvagens. 2.ed. São Paulo: Roca, pp.709-722.

9 Miranda F., Bertassoni A. \& Abba A.M. 2014. Myrmecophaga tridactyla. The IUCN Red List of Threatened Species 2014. Available at: <https://www.iucnredlist.org/species/14224/47441961>.

10 Oliveira M.F. 2001. Morfologia funcional e desenho corporal da cintura pélvica e membros posteriores dos Tamanduás (Mammalia : Xenarthra : Myrmecophagidae). 71f. Belém, PA. Dissertação (Mestrado em Zoologia) - Curso de Pós-Graduação em Ciências Biológicas, Universidade Federal do Pará, Museu Paraense Emílio Goeldi.

11 Orsini H. \& Bondan E.F. 2014. Fisiopatologia do Estresse. In: Cubas Z.S., Silva J.C.R. \& Catão-Dias J.L. (Eds). Tratado de Animais Selvagens. 2.ed. São Paulo: Roca, pp.35-45.

12 Piermattei D., Flo G. \& Decamp C. 2006. Fractures of the Femur and Patella. In: Handbook of Small Animal Orthopedics and Fracture Repair. 4th edn. St. Louis: Elsevier Saunders, pp.512-549.

13 Sesoko N.F. 2012. Estudo anatômico e imaginológico do braço e da coxa em tamanduá-bandeira (Myrmecophaga tridactyla - Linnaeus, 1758) para a determinação de acesso cirúrgico. 60f. Botucatu, SP. Dissertação (Mestrado em Medicina Veterinária) Programa de Pós-Graduação em Medicina Veterinária, Universidade Estadual Paulista "Júlio de Mesquita Filho". 